\title{
Development of a pan-Simbu real-time reverse transcriptase PCR for the detection of Simbu serogroup viruses and comparison with SBV diagnostic PCR systems
}

Melina Fischer, Horst Schirrmeier, Kerstin Wernike, Anne Wegelt, Martin Beer and Bernd Hoffmann*

\begin{abstract}
Background: Schmallenberg virus (SBV), a novel orthobunyavirus of the Simbu serogroup, was first identified in October 2011 in dairy cattle in Germany, where it caused fever, diarrhea and a drop in milk yield. Since then, SBV additionally has been detected in adult sheep and goats. Although symptoms of acute infection were not observed, infection during a vulnerable phase of pregnancy caused congenital malformations and stillbirths. In view of the current situation and the possible emergence of further Simbu serogroup members, a pan-Simbu real-time reverse transcriptase (RT) PCR system for the reliable detection of Simbu serogroup viruses should be developed.

Methods: In this study a pan-Simbu real-time RT-PCR system was established and compared to several SBV real-time RT-PCR assays. All PCR-systems were tested using a panel of different Simbu serogroup viruses as well as several field samples from diseased cattle, sheep and goats originating from all over Germany. Several pan-Simbu real-time RT-PCR products were sequenced via Sanger sequencing. Furthermore, in silico analyses were performed to investigate suitability for the detection of further orthobunyaviruses.

Results: All tested members of the Simbu serogroup $(n=14)$ as well as most of the field samples were successfully detected by the pan-Simbu real-time RT-PCR system. The comparison of this intercalating dye assay with different TaqMan probe-based assays developed for SBV diagnostics confirmed the functionality of the pan-Simbu assay for screening purposes. However, the SBV-TaqMan-assay SBV-S3 delivered the highest analytical sensitivity of less than ten copies per reaction for duplex systems including an internal control. In addition, for confirmation of SBV-genome detection the highly specific SBV-M1 assay was established.

Conclusion: The pan-Simbu real-time RT-PCR system was able to detect all tested members of the Simbu serogroup, most of the SBV field samples as well as three tested Bunyamwera serogroup viruses with a suitable sensitivity. According to in silico analyses, this system seems to be able to detect a broad orthobunyavirus spectrum. As an additional feature of the pan-Simbu real-time RT-PCR system, subsequent species classification via sequencing is feasible. Regarding SBV diagnostics, the performance of the S-segment targeting SBV-S3 assay was superior with respect to the analytical sensitivity.
\end{abstract}

Keywords: Orthobunyavirus, Simbu serogroup, Schmallenberg virus, Real-time RT-PCR

\footnotetext{
* Correspondence: bernd.hoffmann@fli.bund.de

Institute of Diagnostic Virology, Friedrich-Loeffler-Institut, Südufer 10,

D-17493, Greifswald-Insel Riems, Germany
}

\section{Biomed Central




\section{Background}

In October 2011, a novel orthobunyavirus (family: Bunyaviridae) related to the Simbu serogroup viruses affected dairy cattle on a farm near the city of Schmallenberg (North Rhine-Westphalia, Germany). The virus caused clinical signs such as fever, diarrhea and decreased milk yield in dairy cattle. It was finally identified via fullgenome sequencing combined with metagenome analysis and named Schmallenberg virus (SBV) after its geographical origin [1]. Subsequently, SBV was detected in samples from diseased cattle in the Netherlands and in malformed sheep and goat lambs as well as in calves from several European countries [2].

Orthobunyaviruses are characterized by a tripartite, single-stranded, negative-sense RNA genome [3,4]. The three segments are termed according to their size as small (S), medium (M) and large (L) [5]. The genus is divided into 18 serogroups defined by serological relationships. One of the largest serogroups, the Simbu serogroup, comprises at least 25 members [6]. Full-genome sequencing as well as Sanger sequencing and subsequent phylogenetic analyses revealed that SBV is a Simbu serogroup virus, closely related to viruses of the species Sathuperi virus [7]. Sequencing also revealed a complementarity of the 3 prime and the 5 prime end of each segment, a typical feature of the members of the family Bunyaviridae, which leads to the formation of panhandle structures [8].

In this study a pan-Simbu real-time reverse transcriptase (RT) PCR system was developed based on two conserved sequence regions of the L-segment facilitating the amplification of a 279 base pair (bp) fragment for the reliable detection of viruses predominantly from the Simbu serogroup. Furthermore, several diagnostic real-time RTPCR assays for the sensitive and specific detection of the SBV genome were developed and validated. Within the SBV L-segment the SBV-L1 and the SBV-L1.4 assays detected an amplification fragment of $144 \mathrm{bp}$ and $107 \mathrm{bp}$ in length, respectively. The SBV-M1 assay produced a $137 \mathrm{bp}$ PCR product from the M-segment, whereas the published SBV-S3 assay detected an 88 bp region of the S-segment [9]. All of these PCR-systems were tested with a panel of different Simbu serogroup viruses as well as several SBV field samples from diseased cattle, sheep and goats originating from all over Germany.

\section{Results and discussion}

As a first step, from our perspective pivotal members of the Simbu serogroup (Aino virus AINOV, Akabane virus AKAV, Douglas virus DOUV, Oropouche virus OROV, Peaton virus PEAV, Sabo virus SABOV, Sango virus SANV, Sathuperi virus SATV, Shamonda virus SHAV, Shuni virus SHUV, Simbu virus SIMV, Thimiri virus THIV, Tinaroo virus TINV; see Table 1 for species classification) including
SBV and three members of the Bunyamwera serogroup (Batai virus BATV, Bunyamwera virus BUNV, Ngari virus NRIV) were tested to define the detection spectrum of the intercalating dye based pan-Simbu real-time RT-PCR system and the TaqMan probe-based SBV real-time RT-PCR assays (Table 1 ). Although the applied virus titers were partially low $\left(1 \times 10^{2}, 1 \times 10^{2.5}\right.$ or $1 \times 10^{3} 50 \%$ tissue culture infectious doses $\left(\mathrm{TCID}_{50}\right)$ per $\left.\mathrm{ml}\right)$, the pan-Simbu real-time RT-PCR system detected all tested isolates of the Simbu serogroup. DOUV however was recognized with a high quantification cycle $\left(\mathrm{C}_{\mathrm{q}}\right)$ value of 35.7 presumably caused by mismatches in the binding region of the forward primer (Figure 1). Also the detection of THIV seems problematic, yielding the highest $\mathrm{C}_{\mathrm{q}}$-value (36.2) in this investigation. To further characterize the pan-Simbu real-time RT-PCR system the limit of detection and the PCR efficiency were determined using an SBV L-segment standard. The assay reliably detected 100 copies per reaction and displayed an efficiency of $91.6 \%$.

The potential of a subsequent species classification via sequencing was investigated for AINOV, DOUV, PEAV, SABOV, SANV, SATV, SHAV, SHUV and SIMV. Each sequence fragment displayed $100 \%$ sequence identity with the respective Simbu serogroup virus in GenBank, whereas 60-88\% sequence identity was determined among the amplified products, facilitating a reliable differentiation. In silico analyses indicated that this pan-Simbu system is probably able to detect also members from other serogroups, e.g. several members of the California serogroup: Tahyna-, Chatanga-, La Crosse-, Jamestown Canyon-, Snowshoe hare- and Inkoo virus [11] (Figure 1). This assumption was supported by detection of the Bunyamwera serogroup viruses BATV, BUNV and NRIV (Table 1). However, it cannot be excluded that some untested members could be only poorly or not detected at all. Previously published real-time RT-PCR systems are available e.g. for the specific detection of OROV [12] as well as for the simultaneous detection of AKAV and AINOV [13], but to our knowledge this pan-Simbu PCR is the first generic real-time PCR approach for the detection of orthobunyaviruses, predominantly members of the Simbu serogroup.

The different Simbu serogroup viruses and the three Bunyamwera serogroup viruses were also analyzed with SBV-specific real-time RT-PCR assays. With this approach, only the SBV-M1 assay scored negative for the Bunyamwera serogroup viruses and for all Simbu serogroup viruses, with the exception of SBV (Table 1). This assay seemed to be highly specific for SBV. In addition to SBV, the SBV-L1 and the SBV-L1.4 assays also recognized RNA from a SHAV (species Shamonda virus, reassortant comprising the SBV S- and L-segments and the M-segment from an unclassified virus [7]) sample. Compared to each other, these assays displayed markedly different $\mathrm{C}_{\mathrm{q}}$-values for the detection of SHAV presumably due to differences 
Table 1 PCR analysis of Simbu serogroup viruses and Bunyamwera serogroup viruses

\begin{tabular}{|c|c|c|c|c|c|c|c|c|}
\hline \multirow[b]{2}{*}{ Species* } & \multirow[b]{2}{*}{ Virus } & \multirow[b]{2}{*}{ Strain } & \multirow[b]{2}{*}{$\mathrm{TCID}_{50} / \mathrm{ml}$} & \multirow[t]{2}{*}{ Pan Simbu } & \multicolumn{4}{|c|}{ SBV assays } \\
\hline & & & & & M1 & L1 & L1.4 & S3 \\
\hline Akabane & AKAV & OBE-1 & $1 \times 10^{5.4}$ & 33.7 & neg. & neg. & neg. & neg. \\
\hline Akabane & SABOV & AN 9398 & $1 \times 10^{2.5}$ & 29.3 & neg. & neg. & neg. & neg. \\
\hline Akabane & TINV & CSIRO 153 & $1 \times 10^{3.1}$ & 30.2 & neg. & neg. & neg. & neg. \\
\hline Bunyamwera & BATV & 53.2 & $1 \times 10^{5}$ & 32.7 & neg. & neg. & neg. & neg. \\
\hline Bunyamwera & BUNV $^{\#}$ & ATCC VR-87 & $1 \times 10^{4.5}$ & 33.1 & neg. & neg. & neg. & neg. \\
\hline Bunyamwera & NRIV $^{\#}$ & 51 & - & 31.7 & neg. & neg. & neg. & neg. \\
\hline Oropouche & OROV & TRVL 9760 & $1 \times 10^{3.5}$ & 33.2 & neg. & neg. & neg. & neg. \\
\hline Sathuperi & SATV & $\mid-11155$ & $1 \times 10^{2}$ & 28.5 & neg. & neg. & neg. & neg. \\
\hline Sathuperi & Douv & CSIRO 150 & $1 \times 10^{2.5}$ & 35.7 & neg. & neg. & neg. & 25.4 \\
\hline Sathuperi & SBV & BH80-11 & $1 \times 10^{4.3}$ & 30.6 & 22.5 & 23.3 & 23.6 & 21.9 \\
\hline Shamonda & SHAV & An 5550 & $1 \times 10^{2}$ & 30.6 & neg. & 30.0 & 23.9 & 22.2 \\
\hline Shamonda & PEAV & CSIRO 110 & $1 \times 10^{2}$ & 31.4 & neg. & neg. & neg. & neg. \\
\hline Shamonda & SANV & An 5077 & $1 \times 10^{3}$ & 30.1 & neg. & neg. & neg. & neg. \\
\hline Shuni & SHUV & An 10107 & $1 \times 10^{2.5}$ & 28.0 & neg. & neg. & neg. & neg. \\
\hline Shuni & AINOV & Ja N Ar 28 & $1 \times 10^{2}$ & 27.4 & neg. & neg. & neg. & neg. \\
\hline Simbu & SIMV & SA Ar 53 & $1 \times 10^{3}$ & 27.2 & neg. & neg. & neg. & neg. \\
\hline Thimiri & THIV & - & $1 \times 10^{4.1}$ & 36.2 & neg. & neg. & neg. & neg. \\
\hline
\end{tabular}

neg.: negative result; -: not available; pan Simbu: pan-Simbu real-time RT-PCR system; TCID $_{50}$ : 50\% tissue culture infectious doses; M1: highly specific SBV-M1 assay; L1: SBV-L1 assay, L1.4: SBV-L1.4 assay; S3: SBV-S3 assay; ${ }^{*}$ species classification according to [10], SBV [7]; ${ }^{*} 1: 100$ dilution of original RNA; columns 5-9 represent mean $\mathrm{C}_{\mathrm{q}}$-values from duplicates.

in the primer binding capability caused by a slight adjustment of the detection region for the SBV-L1.4 assay. The SBV-S3 assay was able to detect RNA from SBV, SHAV and DOUV (species Sathuperi virus; see Table 1 for species classification). In this case, the detection region of the
SBV-S3 assay on the S-segment is highly similar between SBV and the reassortant SHAV and further seems to be rather similar between the two members of the Sathuperi virus species SBV and DOUV which consequently enables their recognition.

\begin{tabular}{|c|c|c|c|c|c|c|c|c|c|}
\hline & 2880 & 2890 & 2900 & 2910 & & 3140 & 3150 & 3160 & 3170 \\
\hline & $|\ldots| \ldots$ & $|\ldots| \ldots$ & $|\ldots| \ldots$ & $|\ldots| \ldots$ & $\sim \sim \sim$ &.$|\ldots|$ &.$|\ldots|$ & $|\ldots|$ & \\
\hline Schmallenberg (HE649912) & AATATTCGTA & GGCGAATTTG & AGGCAAAAAT & GTGCTTGTAT & $\sim \sim \sim$ & ATCAATGCAG & ACATGTCAAA & ATGGAGTGCC & CAAGA \\
\hline Aino (HE795087) & AATCTTTGTT & GGTGAATTTG & AGGCTAAGAT & GTGCTTATAT & $\sim \sim \sim$ & ATAAATGCTG & ATATGTCAAA & ATGGAGTGCT & CAAGA \\
\hline$\overline{\mathrm{Akab}}$ ane (NC_009894) & AATATTTGTG & GGAGAGTTTG & AAGCTAAAAT & GTGCTTATAC & $\sim \sim \sim$ & ATAAATGCAG & ACATGTCGAA & ATGGAGTGCA & CAAGA \\
\hline$\overline{\text { Douglas }}$ (HĒ̄95090) & GATATTTGTG & GGTGAATTTG & AAGCAAAAAT & GTGCTTATAT & $\sim \sim \sim$ & ATTAATGCAG & ATATGTCAAA & GTGGAGTGCT & CAGGA \\
\hline Oropouche (NC_005776) & AATATTTTTA & GGTGAATTTG & AAGCAAAAAT & GTGTCTGTAC & $\sim \sim \sim$ & ATAAATGCTG & ATATGTCCAA & ATGGAGTGCC & CAAGA \\
\hline Peaton CSIRO $\overline{1} 10$ (HE795093) & AATTTTTGTA & GGAGAGTTTG & AAGCAAAAAT & GTGTTTATAC & $\sim \sim \sim$ & ATTAATGCTG & ATATGTCAAA & ATGGAGTGCA & CAAGA \\
\hline Sabo AN9398 (HE795096) & AATTTTTGTA & GGAGAATTTG & AAGCAAAGAT & GTGCCTCTAT & $\sim \sim \sim$ & ATCAATGCTG & ACATGTCTAA & GTGGAGCGCT & CAAGA \\
\hline Sango AN5077 (HE795099) & AATATTTGTG & GGAGAGTTTG & AAGCCAAGAT & GTGCCTATAC & $\sim \sim \sim$ & ATAAATGCTG & ATATGTCAAA & GTGGAGCGCT & CAGGA \\
\hline Sathuperi (HE795102) & GATATTTGTA & GGTGAGTTTG & AAGCCAAAAT & GTGTTTATAT & $\sim \sim \sim$ & ATCAATGCAG & ATATGTCAAA & GTGGAGTGCT & CAAGA \\
\hline Shamonda AN5550 (HE795105) & AATATTCGTA & GGCGAATTTG & AGGCAAAAAT & GTGCTTGTAT & $\sim \sim \sim$ & ATCAATGCAG & ACATGTCAAA & ATGGAGTGCT & CAGGA \\
\hline 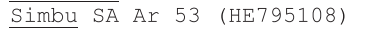 & AATATTTGTT & GGAGAATTTG & AAGCTAAGAT & GTGTTTATAT & $\sim \sim \sim$ & ATAAATGCAG & ACATGTCAAA & ATGGAGTGCA & CAAGA \\
\hline Tahyna (HM243140) & AATATTTGTA & GGGGAGTACG & AAGCCAAAAT & GTGCATGTAT & $\sim \sim \sim$ & ATAAATGCAG & ACATGTCCAA & ATGGAGCGCC & CAGGA \\
\hline Chatanga (HQ734819) & GATTTTCGTA & GGGGAATATG & AAGCTAAAAT & GTGTATGTAT & $\sim \sim \sim$ & ATAAATGCAG & ATATGTCAAA & ATGGAGTGCT & CAAGA \\
\hline Leanyer (HM627178) & AATATATGTA & GGAGAATATG & AAGCAAAATT & GTGTCTGTAT & $\sim \sim \sim$ & ATAAATGCAG & ATATGTCAAA & ATGGAGTGCT & CAAGA \\
\hline La Crosse (GU206125) & GATATTCGTT & GGAGAATATG & AAGCTAAAAT & GTGTATGTAC & $\sim \sim \sim$ & ATAAATGCAG & ACATGTCTAA & ATGGAGTGCT & CAGGA \\
\hline Jamestown Canyon (HM007358) & AATATTTGTG & GGAGAATACG & AGGCTAAAAT & GTGTATGTAT & $\sim \sim \sim$ & ATCAATGCAG & ATATGTCCAA & ATGGAGTGCC & CAGGA \\
\hline Tensaw (FJ943510) & AATTTTCGTT & GGTGAATTTG & AAGCAAAAAT & GTGCATGTAT & $\sim \sim \sim$ & ATAAATGCAG & ATATGTCCAA & ATGGAGTGCA & CAAGA \\
\hline Snowshoe hare (EU203678) & AATATTTGTT & GGAGAATATG & AAGCTAAAAT & GTGTATGTAT & $\sim \sim \sim$ & ATCAATGCAG & ACATGTCGAA & ATGGAGTGCA & CAAGA \\
\hline La Crosse (NC_004108) & GATATTCGTT & GGAGAATATG & AAGCTAAAAT & GTGTATGTAC & $\sim \sim \sim$ & ATAAATGCAG & ATATGTCTAA & ATGGAGTGCT & CAGGA \\
\hline Bunyamwera (N)_001925) & GATATTCGTT & GGAGAATTTG & AAGCTAAAAT & GTGTATGTAT & $\sim \sim \sim$ & ATAAATGCAG & ACATGTCAAA & ATGGAGTGCT & CAAGA \\
\hline Inkoo (EU789573) & AATATTTGTA & GGGGAATATG & AGGCTAAAAT & GTGTATGTAT & $\sim \sim \sim$ & ATAAATGCAG & ATATGTCTAA & ATGGAGTGCT & CAAGA \\
\hline $\begin{array}{l}\text { Consensus } \\
\text { panOBV-L-2959F }\end{array}$ & $\begin{array}{r}\text { RATHTWYKTD } \\
\mathrm{TT}\end{array}$ & $\begin{array}{l}\text { GGNGARTWYG } \\
\text { GGAGARTATG }\end{array}$ & $\begin{array}{l}\text { ARGCHAARWT } \\
\text { ARGCTAARAT }\end{array}$ & $\begin{array}{l}\text { GTGYHTVTAY } \\
\text { GTG } \longrightarrow\end{array}$ & & & YATGTCNAA & RTGGAGYGCH & $R G A$ \\
\hline panOBV-L-3274R (rev-com) & & & & & & $\longleftarrow \mathrm{G}$ & AYATGTCNAA & ATGGAGTGCT & \\
\hline \multicolumn{10}{|c|}{$\begin{array}{l}\text { Figure } 1 \text { Comparison of the consensus sequences of different Orthobunyavirus species. Sequences are in regard to the primer region of } \\
\text { the L-segment. The nucleotide positions are based on the Schmallenberg virus genome [GenBank: HE649912]. Letters in bold represent nucleotides } \\
\text { with mismatch to the primer sequence. Simbu serogroup viruses are underlined. }\end{array}$} \\
\hline
\end{tabular}


To evaluate the sensitivity of the different assays a $\log _{10}$ dilution series $\left(10^{-2}\right.$ to $10^{-8}$ dilution) of SBV-RNA extracted from a cell culture sample (BH80/11-4, initial titer $1 \times 10^{6.3} \mathrm{TCID}_{50} / \mathrm{ml}$ ) was tested (Table 2). The maximum detection rate of the pan-Simbu real-time RT-PCR system was seen at the $10^{-4}$ dilution; due to recognition up to this dilution step, the system seems sufficient for a preliminary screening of undiluted field samples of good quality. The SBV-S3 assay provided the best performance with a reliable recognition (detection of duplicate samples) of every dilution step up to the $10^{-7}$ dilution in combination with the lowest $\mathrm{C}_{\mathrm{q}}$-values compared to the other assays. Furthermore, the SBV-L1 and SBV-L1.4 assays displayed comparable $\mathrm{C}_{\mathrm{q}}$-values for the dilution series with a reliable detection up to a dilution of $10^{-6}$. The SBV-specific SBVM1 assay allowed a positive detection up to the dilution step $10^{-5}$. Despite its lower sensitivity, the SBV-M1 assay is a valuable tool for distinguishing SBV from other orthobunyaviruses to yield a precise diagnosis in regions where multiple orthobunyaviruses occur.

In addition to the sensitivity analysis, the pan-Simbu real-time RT-PCR system, the SBV-M1, the SBV-L1, the SBV-L1.4 and the SBV-S3 assays were tested using 47 RNA samples from SBV-suspicious field material as well as a defined sample from an SBV challenge experiment [1] (Table 3). In this approach, the SBV-S3 assay showed the lowest $\mathrm{C}_{\mathrm{q}}$-values among the tested assays and recognized 40 positive samples, while eight isolates scored negative (pre-tested as negative by SBV-L1 assay).

The pan-Simbu real-time RT-PCR system detected 32 positive samples out of the $40 \mathrm{SBV}-\mathrm{S} 3$-positive samples. Three samples which had $\mathrm{C}_{\mathrm{q}}$-values above 28 using the SBV-S3 assay scored doubtful with only one positive duplicate using the pan-Simbu real-time RT-PCR system. Eight samples defined as SBV-negative with the SBV-S3 assay, and additional five samples with a genome load of

Table 2 Evaluation of the sensitivity of the individual assays using an SBV-RNA dilution series

\begin{tabular}{lccccc}
\hline & Pan Simbu & \multicolumn{4}{c}{ SBV assays } \\
\cline { 3 - 6 } Sample* $^{*}$ & & M1 & L1 & L1.4 & S3 \\
\hline SBV 10 & 30.6 & 22.5 & 23.3 & 23.6 & 21.9 \\
SBV 10 & 34.5 & 26.1 & 26.8 & 26.6 & 24.5 \\
SBV 10 & 38.2 & 29.2 & 30.1 & 30.1 & 27.8 \\
SBV 10 & neg. & 32.6 & 33.3 & 33.3 & 31.1 \\
SBV 10 & neg. & $41.1^{-4}$ & 36.4 & 36.8 & 34.6 \\
SBV 10 & neg. & neg. & neg. & $39.6^{\#}$ & 37.8 \\
SBV 10 & neg. & neg. & neg. & neg. & neg. \\
\hline
\end{tabular}

* $\log 10$ dilution series of SBV RNA extracted from cell culture sample BH80/11-4 (KC/BHK), initial titer $1 \times 10^{6.3} \mathrm{TCID} 50 / \mathrm{ml}$; " only one of the duplicates positive; neg.: negative result; pan Simbu: pan-Simbu real-time RT-PCR system; M1: SBV-M1 assay; L1: SBV-L1 assay, L1.4: SBV-L1.4 assay; S3: SBV-S3 assay; columns 2-6 represent mean $\mathrm{C}_{\mathrm{q}}$-values from duplicates.

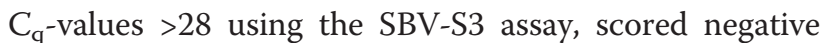
in the pan-Simbu real-time RT-PCR system. In general, the pan-Simbu real-time RT-PCR system produced higher $\mathrm{C}_{\mathrm{q}}$-values than the SBV-specific assays (Table 3). Therefore, the sensitivity of the pan-Simbu system presumably was not sufficient for samples containing a low viral genome load. Nevertheless, the pan-Simbu real-time RT-PCR system was able to detect field samples with $\mathrm{C}_{\mathrm{q}^{-}}$values below 28 reliably measured by the SBV-S3 assay as well as the animal trial sample (Table 3).

Furthermore, the SBV-M1 assay revealed 39 positive and nine negative samples (Table 3). One SBV-S3 positive sample $\left(C_{\mathrm{q}} 37\right)$ scored negative, presumably due to the reduced sensitivity of the SBV-M1 assay. The SBV-L1 assay detected 37 positive and eleven negative samples. Three samples tested positive with $\mathrm{C}_{\mathrm{q}}$-values $>31$ in the SBV-S3 assay scored negative. The SBV-L1.4 assay yielded comparable $\mathrm{C}_{\mathrm{q}}$-values to the SBV-L1 assay, but recognized 38 positive samples, and two doubtful results (SBV-S3 $\mathrm{C}_{\mathrm{q}^{-}}$ values $>34$ ) with only one positive duplicate displaying a $\mathrm{Cq}$-value higher than 38. Eight isolates scored negative (in concordance with SBV-S3) with both SBV-L assays.

Finally, the analytical sensitivity of the SBV-S3 singletarget assay in comparison to two different SBV-S3 duplex assays including internal amplification controls was evaluated (Table 4). The single-target assay detected a dilution of $2 \times 10^{-1}$ copies $/ \mu$ l, which corresponded to one RNA copy per reaction. Both duplex assays were able to detect at most $2 \times 10^{0}$ copies $/ \mu \mathrm{l}(10$ copies per reaction), while simultaneous co-amplification of either IC2-RNA $\left(\sim \mathrm{C}_{\mathrm{q}} 26\right)$ or the housekeeping gene beta-actin $\left(\sim \mathrm{C}_{\mathrm{q}} 29\right)$ was performed reliably.

\section{Conclusion}

In conclusion, the pan-Simbu real-time RT-PCR system was able to detect all tested members of the Simbu serogroup as well as most of the SBV field samples and three Bunyamwera serogroup viruses with an acceptable sensitivity for screening diagnostics. Although we were not able to test all 25 members of the Simbu serogroup, we investigated key-members with clinical or economic importance like OROV and AKAV [6]. According to in silico analyses the system seems to be able to detect a broad spectrum of orthobunyaviruses (Figure 1) as supported by detection of members from the Bunyamwera serogroup (Table 1). The pan-Simbu real-time RT-PCR system is based on two highly conserved sequence regions of the L-segment which were selected as primer binding sites. As an additional feature of the novel system, these primers enclosed a variable sequence region, which is suitable for subsequent species classification via sequencing, avoiding misdiagnosis. This opportunity was confirmed exemplarily for AINOV, DOUV, PEAV, SABOV, SANV, SATV, SHAV, SHUV and SIMV. The here 
Table 3 Comparison of pan-Simbu real-time RT-PCR and SBV diagnostic PCRs using field samples

\begin{tabular}{|c|c|c|c|c|c|c|c|c|}
\hline \multirow[b]{2}{*}{ Sample } & \multirow[b]{2}{*}{ Material } & \multirow[b]{2}{*}{ Species } & \multirow[b]{2}{*}{ Origin } & \multirow[t]{2}{*}{ Pan Simbu } & \multicolumn{4}{|c|}{ SBV assays } \\
\hline & & & & & M1 & L1 & L1.4 & S3 \\
\hline 1 & Brain & Sheep (lamb) & NRW & 34.1 & 27.2 & 27.2 & 26.7 & 23.7 \\
\hline 2 & Cerebellum & Goat (goatling) & NRW & 32.3 & 26.3 & 25.5 & 26.3 & 22.5 \\
\hline 3 & Med. obl. & Goat (goatling) & NRW & 36.0 & 31.0 & 28.3 & 29.1 & 25.5 \\
\hline 4 & Brain & Goat (goatling) & NRW & 34.4 & 28.3 & 24.5 & 24.9 & 21.5 \\
\hline 5 & Inter. Candolis & Goat (goatling) & NRW & 33.2 & 27.3 & 25.5 & 26.2 & 22.6 \\
\hline 6 & Brain & Sheep (fetus) & NRW & 39.3 & 38.2 & 37.8 & 39.4 & 33.9 \\
\hline 7 & Blood & Sheep (lamb) & NRW & 38.1 & 36.6 & 35.4 & 36.0 & 32.2 \\
\hline 8 & Med. obl. & Sheep (lamb) & NRW & 35.4 & 28.0 & 29.9 & 30.8 & 27.1 \\
\hline 9 & Cerebellum & Sheep (lamb) & NRW & 38.3 & 34.8 & 34.3 & 34.7 & 31.7 \\
\hline 10 & Cerebrum & Sheep (lamb) & NRW & 37.0 & 32.6 & 32.2 & 33.0 & 31.4 \\
\hline 11 & Spinal cord & Sheep (lamb) & NRW & 36.7 & 30.5 & 30.6 & 31.7 & 28.1 \\
\hline 12 & Blood & Sheep (lamb) & NRW & neg. & 32.0 & neg. & 36.1 & 31.9 \\
\hline 13 & Med. obl. & Sheep (lamb) & NRW & 37.2 & 32.6 & 32.1 & 33.0 & 28.3 \\
\hline 14 & Cerebellum & Sheep (lamb) & NRW & 38.7 & 31.4 & 33.8 & 35.5 & 30.4 \\
\hline 15 & Cerebrum & Sheep (lamb) & NRW & 36.6 & 30.7 & 29.9 & 30.5 & 26.3 \\
\hline 16 & Cerebrum & Sheep (lamb) & NRW & 32.6 & 27.0 & 25.4 & 26.3 & 23.1 \\
\hline 17 & Med. obl. & Sheep (lamb) & NRW & 39.0 & 34.2 & 37.2 & 38.6 & 32.3 \\
\hline 18 & Cerebrum & Sheep (lamb) & NRW & 29.7 & 22.6 & 22.5 & 21.3 & 16.8 \\
\hline 19 & Cerebrum & Sheep (lamb) & NRW & $39.9^{*}$ & neg. & neg. & $39.2^{*}$ & 37.0 \\
\hline 20 & EDTA blood & Sheep & Hesse & $38.8^{*}$ & 34.8 & 34.5 & 34.7 & 30.3 \\
\hline 21 & EDTA blood & Sheep & Hesse & neg. & 38.6 & 37.4 & 37.3 & 34.7 \\
\hline 22 & Organ material & Sheep & Hesse & 28.9 & 25.5 & 20.3 & 20.1 & 15.2 \\
\hline 23 & Cerebrum & Sheep (lamb) & Hesse & 38.1 & 29.8 & 31.0 & 31.7 & 28.1 \\
\hline 24 & Brain stem & Sheep & LS & 36.4 & 32.4 & 28.7 & 29.3 & 26.4 \\
\hline 25 & Cortex & Sheep & LS & 36.5 & 33.2 & 30.1 & 30.7 & 27.5 \\
\hline 26 & Brain & Sheep (lamb) & LS & 38.0 & 32.9 & 31.3 & 31.1 & 28.6 \\
\hline 27 & Brain & Goat (goatling) & BW & 31.9 & 25.8 & 21.7 & 22.1 & 18.1 \\
\hline 28 & Serum & Goat (goatling) & BW & $39.6^{*}$ & 35.5 & 32.0 & 32.4 & 28.8 \\
\hline 29 & Cruor & Goat (goatling) & BW & 34.1 & 30.2 & 28.5 & 29.0 & 25.5 \\
\hline 30 & Cerebellum & Sheep & SA & 34.1 & 31.1 & 30.6 & 30.4 & 28.0 \\
\hline 31 & Cerebrum & Sheep & SA & 36.7 & 32.7 & 31.7 & 31.8 & 29.2 \\
\hline 32 & Cerebrum & Sheep & SA & 29.8 & 25.3 & 22.2 & 22.4 & 21.8 \\
\hline 33 & Brain & Sheep (fetus) & Bavaria & 33.7 & 30.2 & 25.0 & 24.6 & 22.0 \\
\hline 34 & Brain & Sheep (fetus) & Bavaria & neg. & 33.8 & 36.0 & 36.7 & 32.9 \\
\hline 35 & EDTA blood & Sheep (fetus) & Bavaria & neg. & 36.2 & neg. & $38.7^{*}$ & 34.9 \\
\hline 36 & Organ material & Sheep (lamb) & $\mathrm{HH}$ & neg. & neg. & neg. & neg. & neg. \\
\hline 37 & Organ material & Sheep & $\mathrm{HH}$ & 36.5 & 26.4 & 27.5 & 27.3 & 25.4 \\
\hline 38 & Organ material & Sheep (lamb) & $\mathrm{SH}$ & 38.9 & 32.9 & 31.2 & 30.7 & 27.7 \\
\hline 39 & Serum & Cattle & $\mathrm{TH}$ & neg. & neg. & neg. & neg. & neg. \\
\hline 40 & Cerebrum & Bison (fetus) & $\mathrm{RP}$ & 29.4 & 22.2 & 21.1 & 21.6 & 15.8 \\
\hline 41 & Cerebrum & Sheep & BB & neg. & 33.6 & 32.3 & 32.7 & 28.2 \\
\hline 42 & Blood & Cattle & animal trial & 29.7 & 20.4 & 21.9 & 22.9 & 21.1 \\
\hline 43 & Blood & Sheep (lamb) & NRW & neg. & neg. & neg. & neg. & neg. \\
\hline
\end{tabular}


Table 3 Comparison of pan-Simbu real-time RT-PCR and SBV diagnostic PCRs using field samples (Continued)

\begin{tabular}{|c|c|c|c|c|c|c|c|}
\hline 44 & Med. obl. & Sheep (lamb) & NRW & neg. & neg. & neg. & neg. \\
\hline 45 & Cerebellum & Sheep (lamb) & NRW & neg. & neg. & neg. & neg. \\
\hline 46 & Cerebrum & Sheep (lamb) & NRW & neg. & neg. & neg. & neg. \\
\hline 47 & Spleen & Sheep (lamb) & NRW & neg. & neg. & neg. & neg. \\
\hline 48 & Muscle & Sheep (lamb) & NRW & neg. & neg. & neg. & neg. \\
\hline
\end{tabular}

med. obl.: medulla oblongata; organ material consists of cerebrum, cerebellum, spleen; LS: Lower Saxony; NRW: North Rhine-Westphalia; SH: Schleswig-Holstein; TH: Thuringia; RP: Rhineland-Palatinate; BW: Baden-Württemberg; HH: Hamburg; BB: Brandenburg; SA: Saxony-Anhalt; * only one of the duplicates positive; neg.: negative result; pan Simbu: pan-Simbu real-time RT-PCR system; M1: SBV-M1 assay; L1: SBV-L1 assay, L1.4: SBV-L1.4 assay; S3: SBV-S3 assay; columns 5-9 represent mean $\mathrm{C}_{\mathrm{q}}$-values from duplicates.

described pan-Simbu PCR system is therefore the first available tool for a broad screening of samples predominantly for Simbu serogroup virus genomes and could also allow the identification of related orthobunyaviruses in mammalian but also insect vector samples.

For the specific detection of SBV-genome, the SBV-S3 assay turned out to be the most suitable system with the highest sensitivity and reliability. The analytical sensitivity of the SBV-S3 single-target assay as well as the two duplex assays including an internal amplification control (IC2-RNA, beta-actin respectively) were determined as one copy per reaction performing the single-target assay and ten copies per reaction using both duplex systems. Furthermore, the SBV-S3 assay was also able to detect the highly related Sathuperi virus species member DOUV as well as the reassortant SHAV apart from SBV.

\section{Methods}

\section{Samples and RNA isolation}

Viral RNA from field samples, from blood of an experimentally infected calf [1] (Table 3) as well as from cell culture material of the Simbu serogroup viruses namely AINOV, AKAV, DOUV, OROV, PEAV, SABOV, SANV, SATV, SHAV, SHUV, SIMV, THIV, TINV [6] and from the Bunyamwera serogroup viruses BATV [14], BUNV, NRIV was extracted manually using the QIAmp Viral RNA Mini
Kit (Qiagen, Hilden, Germany) according to the manufacturer's instructions or using the MagNA Pure LC 2.0 in combination with the MagNA Pure LC Total Nucleic Acid Isolation Kit (Roche Diagnostics, Mannheim, Germany) according to the manufacturer's recommendations. All samples were stored at $-20^{\circ} \mathrm{C}$ until use.

\section{Oligonucleotides and primer design}

The sequences of primers and probes are listed in Table 5. For the pan-Simbu assay, primers were selected by analyzing the consensus sequence of the L-segment of 70 orthobunyaviruses available in GenBank. The locations of the primers and potential mismatches with the L-segment of different orthobunyaviruses are depicted in Figure 1.

The selection of primers and probes of the SBV realtime RT-PCR assays was based on the first available sequence data of the SBV isolate BH80/11-4 [1] and was supported by the software package Beacon Designer 7.0 (PremierBiosoft, Palo Alto, USA).

All oligonucleotides were synthesized by metabion (metabion international AG, Martinsried, Germany) and stored at $-20^{\circ} \mathrm{C}$ until use.

\section{Pan-Simbu real-time RT-PCR}

In order to allow a broad detection of members of the Simbu serogroup a pan-Simbu real-time RT-PCR was

Table 4 Evaluation of the analytical sensitivity of the SBV-S3 assay using an SBV-S3 standard

\begin{tabular}{|c|c|c|c|c|c|}
\hline \multirow[b]{2}{*}{ Concentration } & \multicolumn{3}{|c|}{ Viral genome } & \multicolumn{2}{|c|}{ Internal control } \\
\hline & Single & Duplex IC2 & Duplex $\beta$-actin & Duplex IC2 & Duplex $\beta$-actin \\
\hline $2 \times 10^{6}$ & 16.3 & 16.6 & 16.5 & 26.7 & 29.4 \\
\hline $2 \times 10^{5}$ & 19.5 & 19.8 & 19.8 & 26.2 & 28.5 \\
\hline $2 \times 10^{4}$ & 23.0 & 23.1 & 23.3 & 26.1 & 28.3 \\
\hline $2 \times 10^{3}$ & 26.3 & 26.4 & 26.5 & 26.2 & 28.2 \\
\hline $2 \times 10^{2}$ & 29.6 & 29.8 & 30.0 & 26.2 & 28.3 \\
\hline $2 \times 10^{1}$ & 32.5 & 32.7 & 33.6 & 26.3 & 28.4 \\
\hline $2 \times 10^{0}$ & 34.4 & 34.8 & 34.6 & 26.4 & 28.5 \\
\hline $2 \times 10^{-1}$ & 37.6 & $39.3^{*}$ & neg. & 26.4 & 28.7 \\
\hline
\end{tabular}

concentration in copies/ $\mu$ l; single: SBV-S3 single-target assay; duplex IC2: SBV-S3 duplex assay based on IC2 RNA; duplex $\beta$-actin: SBV-S3 duplex assay with co-amplification of beta-actin gene; *only one of the duplicates positive; neg.: negative result; columns 2-6 represent mean $C_{\mathrm{q}}$-values from duplicates. 
Table 5 Oligonucleotides used in this study

\begin{tabular}{|c|c|c|c|c|c|}
\hline Assay & Name & Oligonucleotide & Position (nt) & Sequence $\left(5^{\prime}-3^{\prime}\right)$ & Location \\
\hline \multirow[t]{2}{*}{ Pan-Simbu PCR } & panOBV-L-2959 F & Primer & $2888-3167$ & TTG GAG ART ATG ARG CTA ARA TGT G & L-Segment \\
\hline & panOBV-L-3274R & Primer & & TGA GCA CTC CAT TTN GAC ATR TC & \\
\hline \multirow[t]{3}{*}{ SBV-M1 } & SBV-M1-213 F & Primer & $1690-1827$ & TCA ATT CAG CAA GTA ACA TAC AAT GG & M-Segment \\
\hline & SBV-M1-350R & Primer & & CGT GGT CTG TCT TGG TTG ATG & \\
\hline & SBV-M1-240FAM & Probe & & FAM-AAG CAC TGG CCC GAA GTT TCA CCT-BHQ1 & \\
\hline \multirow[t]{3}{*}{ SBV-L1 } & SBV-L1-11 F & Primer & $367-511$ & TTG CCG TाT GAT TाT GAA GTT GTG & L-Segment \\
\hline & SBV-L1-155R & Primer & & TCA GGG ATC GCA AAT TAA AGA ACC & \\
\hline & SBV-L1-36FAM & Probe & & FAM-TCA TCC GTG CTG ACC CTC TGC GAG-BHQ1 & \\
\hline \multirow[t]{3}{*}{ SBV-L1.4 } & SBV-L1.2 F & Primer & $361-468$ & TCA GAA TTG CCG TाT GAT TाT GAA G & L-Segment \\
\hline & SBV-L1.4R & Primer & & GTT GAG CGG CCC AAA TAT TTC C & \\
\hline & SBV-L1-36FAM & Probe & & FAM-TCA TCC GTG CTG ACC CTC TGC GAG-BHQ1 & \\
\hline \multirow[t]{3}{*}{ SBV-S3* } & SBV-S-382 F & Primer & $382-469$ & TCA GAT TGT CAT GCC CCT TGC & S-Segment \\
\hline & SBV-S-469R & Primer & & TTC GGC CCC AGG TGC AAA TC & \\
\hline & SBV-S-408FAM & Probe & & FAM-TTA AGG GAT GCA CCT GGG CCG ATG GT-BHQ1 & \\
\hline
\end{tabular}

$\mathrm{N}$ : any base; R: purine base; FAM: 6-carboxyfluorescein; HEX: 5'-hexachlorofluorescein; BHQ1: black hole quencher 1; positions according to [1] accession numbers [GenBank: HE649912-HE649914]; * protocol according to [9].

developed using the OneStep RT-PCR Kit (Qiagen, Hilden, Germany). The assay was optimized using a total reaction volume of $25 \mu \mathrm{l}$. For one reaction $8 \mu \mathrm{l}$ RNase-free water, $5 \mu \mathrm{l}$ 5x OneStep RT-PCR Buffer, $1 \mu$ l OneStep RT-PCR Enzyme Mix, $1 \mu \mathrm{l}$ dNTP Mix (10 mM each), $1 \mu \mathrm{l}$ ResoLight Dye (Roche, Mannheim, Germany), $2 \mu$ l of each primer (panOBV-L-2959 F, panOBV-L-3274R; $10 \mu \mathrm{M}$ each; Table 5) and $5 \mu$ l RNA template or RNase free water for the no template control (NTC) was used. The following thermal program was applied 1 cycle of $50^{\circ} \mathrm{C}$ for $30 \mathrm{~min}$ and $95^{\circ} \mathrm{C}$ for $15 \mathrm{~min}$, followed by 40 cycles of $95^{\circ} \mathrm{C}$ for $30 \mathrm{~s}, 55^{\circ} \mathrm{C}$ for $30 \mathrm{~s}, 72^{\circ} \mathrm{C}$ for $30 \mathrm{~s}$ and $78^{\circ} \mathrm{C}$ for $15 \mathrm{~s}$. The collection of the fluorescence data was performed during the $78^{\circ} \mathrm{C}$ elongation step.

\section{PCR efficiency and limit of detection for pan-Simbu real-time RT-PCR}

The PCR efficiency and the limit of detection for the pan-Simbu real-time RT-PCR were determined using an SBV L-segment plasmid (L-segment sequence according to GenBank: HE649912 in X8 $8 \mathrm{~T}$ backbone). The exact number of plasmid molecules was calculated (http:// www.molbiol.edu.ru/eng/scripts/01_07.html) and a $\log _{10}$ dilution series $\left(2 \times 10^{6}\right.$ to $2 \times 10^{-1}$ copies $\left./ \mu \mathrm{l}\right)$ was prepared. This dilution series was tested with the pan-Simbu real-time RT-PCR in four replicates. PCR efficiency was calculated by the CFX manager software 3.0 (Bio-Rad Laboratories Inc., Hercules, USA).

\section{Sequencing of pan-Simbu real-time RT-PCR products} For species classification of members of the Simbu serogroup (i.e. AINOV, DOUV, PEAV, SABOV, SANV, SATV,
SHAV, SHUV and SIMV) obtained PCR products of the pan-Simbu real-time RT-PCR were analyzed on a $1.5 \%$ agarose gel and purified using the QIAquick Gel Extraction Kit (Qiagen, Hilden, Germany) according to the manufacturer's instructions. Direct sequencing was carried out in both directions by termination cycle sequencing using the Big Dye Terminator Mix 1.1 (Applied Biosystems, Carlsbad, USA) with the same primers used for PCR product amplification. The assay was optimized by using a total reaction volume of $10 \mu \mathrm{l}$. Briefly, for one reaction $1 \mu \mathrm{l}$ RNase-free water, $1 \mu \mathrm{l}$ of $5 \mathrm{x}$ Sequencing Buffer, $2 \mu \mathrm{l}$ Big Dye Terminator Mix 1.1 and $1 \mu$ of the according primer $(5 \mu \mathrm{M})$. The following thermal program was applied 1 cycle of $96^{\circ} \mathrm{C}$ for $1 \mathrm{~min}$ followed by 26 cycles of $95^{\circ} \mathrm{C}$ for $15 \mathrm{~s}$, $53^{\circ} \mathrm{C}$ for $10 \mathrm{~s}$, and $60^{\circ} \mathrm{C}$ for $4 \mathrm{~min}$. After that, cycle sequencing products were purified with DyeEx 2.0 Spin Kit (Qiagen, Hilden, Germany). The nucleotide sequences were resolved in an ABI 3130 Genetic Analyzer (Applied Biosystems, Carlsbad, USA). Sequences were aligned and analyzed in BioEdit [15] (version 7.1.7).

\section{SBV-specific real-time RT-PCR assays}

For detection of SBV-RNA several diagnostic assays (named SBV-M1, SBV-L1, SBV-L1.4 and SBV-S3) were tested using the AgPath-ID ${ }^{\mathrm{im}}$ One-Step RT-PCR Kit (Applied Biosystems, Carlsbad, USA). The assays were optimized using a total reaction volume of $25 \mu \mathrm{l}$. Briefly, for one single reaction $4.5 \mu \mathrm{l}$ RNase-free water, $12.5 \mu \mathrm{l} 2 \times$ RT-PCR buffer, $1 \mu \mathrm{l} 25 \times$ RT-PCR enzyme mix, $5 \mu \mathrm{l}$ RNA template or RNase free water for the no template control (NTC) and $2 \mu \mathrm{l}$ of the according primer-probe mix (Table 5) were combined. Based on stock solutions of the 
primer and probes of $100 \mathrm{pmol} / \mu \mathrm{l}(100 \mu \mathrm{M})$, the different primer-probe mixes were created. For each assay $20 \mu \mathrm{l}$ of the relevant forward and reverse primer, $3.75 \mu \mathrm{l}$ of the 6-carboxyfluorescein (FAM) labeled probe were mixed in $156.25 \mu \mathrm{l} 0.1 \times$ Tris-EDTA (TE) buffer. Thus, a final concentration of $10 \mu \mathrm{M}$ for each primer and $1.88 \mu \mathrm{M}$ for each probe was used. The following thermal program was applied: 1 cycle of $45^{\circ} \mathrm{C}$ for $10 \mathrm{~min}$ and $95^{\circ} \mathrm{C}$ for $10 \mathrm{~min}$, followed by 45 cycles of $95^{\circ} \mathrm{C}$ for $15 \mathrm{~s}, 56^{\circ} \mathrm{C}$ for $20 \mathrm{~s}$, and $72^{\circ} \mathrm{C}$ for $30 \mathrm{~s}$.

\section{Generation of a SBV-S3 PCR standard and identification of the analytical sensitivity}

In order to determine the analytical sensitivity of the SBV-S3 assay, an SBV-S3 standard was generated. Therefore, the gel-purified SBV-S3 PCR fragment was ligated into the vector pGEM-Teasy (Promega, Mannheim, Germany). Plasmids were amplified in Escherichia coli DH10B (Invitrogen, Carlsbad, USA) and purified by Qiagen Plasmid Mini and Midi Kits (Qiagen, Hilden, Germany) according to standard protocols. The identity of the plasmids was confirmed by EcoRI-digestion and sequencing. Linearized and purified plasmid DNA was in vitro transcribed with the RiboMAX Large Scale RNA Production Systems (Promega, Mannheim, Germany) and subsequently a DNase I digestion was performed using the SP6/T7 Transcription Kit (Roche Diagnostics, Mannheim, Germany) according to the manufacturer's instructions. During purification of the in vitro transcribed RNA using the RNeasy Kit (Qiagen, Hilden, Germany) a second oncolumn DNase I digestion according to the manufacturer's recommendations was implemented. The exact number of RNA molecules was calculated as described [16] and a $\log _{10}$ dilution series $\left(2 \times 10^{6}\right.$ to $2 \times 10^{-1}$ copies/ $\left.\mu \mathrm{l}\right)$ was prepared. RNA was stored until use at $-20^{\circ} \mathrm{C}$. The analytical sensitivity was evaluated for the SBV-S3 single-target assay, for a SBV-S3 duplex assay with a universal internal control (IC) system according to [17] based on heterologous RNA and for a second SBV-S3 duplex system using the co-amplification of the housekeeping gene beta-actin as internal control [18].

All real-time PCR reactions were carried out in BioRad 96-well PCR plates using a CFX96 quantitative PCR system (Bio-Rad Laboratories Inc., Hercules, USA). All these analyses were performed as technical duplicates and the quantification cycle $\left(\mathrm{C}_{\mathrm{q}}\right)$ values listed in the tables represent the mean $\mathrm{C}_{\mathrm{q}}$-value. In all experiments a qualified number of controls, namely no template controls (NTC), internal controls (IC) and positive controls (PC), were co-amplified.

\section{Abbreviations}

AINOV: Aino virus; AKAV: Akabane virus; BATV: Batai virus; BUNV: Bunyamwera virus; DOUV: Douglas virus; NRIV: Ngari virus; OROV: Oropouche virus; PEAV: Peaton virus; SABOV: Sabo virus; SANV: Sango virus; SATV: Sathuperi virus; SBV: Schmallenberg virus; SHAV: Shamonda virus; SHUV: Shuni virus; SIMV: Simbu virus; THIV: Thimiri virus; TINV: Tinaroo virus; NTC: No template control; IC: Internal control; PC: Positive control; $C_{q}$ : Quantification cycle; RTPCR: Reverse transcriptase polymerase chain reaction.

\section{Competing interests}

The authors declare that they have no competing interests.

\section{Authors' contributions}

MF BH designed the study. MF performed the laboratory experiments and analyzed the data. MF BH KW MB wrote the manuscript. HS, KW performed the cell culture and titer determination. AW constructed the SBV-S3 standard. MF HS KW AW BH MB contributed to final the manuscript preparation. All authors read and approved the final manuscript.

\section{Acknowledgements}

We thank Christian Korthase, Anja Landmesser, Karin Lissek and Patrick Zitzow for excellent technical assistance as well as Dr. Dirk Höper and Dr. Katja Goller for providing sequence information. Simbu serogroup viruses were kindly provided by Prof. Robert B. Tesh (University of Texas, Galveston, USA) and Dr. Peter Kirkland (Elizabeth Macarthur Agriculture Institute, New South Wales, Australia). BATV was kindly provided by Dr. Jonas Schmidt-Chanasit (Bernhard Nocht Institute for Tropical Medicine, Hamburg, Germany). BUNV and NRIV RNA was kindly provided by Dr. Martin Eiden. The SBV L-segment plasmid was kindly provided by Dr. llona Reimann. This work was supported by the European Union FP7 project "European Management Platform for Emerging and Re-emerging Infectious Disease Entities (EMPERIE; no. 223498)".

Received: 28 August 2013 Accepted: 29 October 2013

Published: 5 November 2013

\section{References}

1. Hoffmann B, Scheuch $M$, Höper D, Jungblut $R$, Holsteg M, Schirrmeier $H$, Eschbaumer M, Goller KV, Wernike K, Fischer M, Breithaupt A, Mettenleiter TC, Beer M: Novel orthobunyavirus in cattle, europe, 2011. Emerg Infect Dis 2012, 18(3):469-472.

2. Beer M, Conraths FJ, van der Poel WHM: 'Schmallenberg virus' - a novel orthobunyavirus emerging in Europe. Epidemiol Infect 2012, 141(1):1-8.

3. Bishop DH, Calisher CH, Casals J, Chumakov MP, Gaidamovich SY, Hannoun C, Lvov DK, Marshall ID, Oker-Blom N, Pettersson RF, Porterfield JS, Russell PK, Shope RE, Westaway EG: Bunyaviridae. Intervirology 1980, 14(3-4):125-143.

4. Walter $C T$, Barr JN: Recent advances in the molecular and cellular biology of bunyaviruses. J Gen Virol 2011, 92(Pt 11):2467-2484.

5. Chowdhary R, Street C, Travassos Da-Rosa A, Nunes M, Tee KK, Hutchison SK, Vasconcelos PF, Tesh RB, Lipkin WI, Briese T: Genetic characterization of the Wyeomyia group of orthobunyaviruses and their phylogenetic relationships. J Gen Virol 2012, 93(Pt 5):1023-1034.

6. Saeed MF, Li L, Wang H, Weaver SC, Barrett ADT: Phylogeny of the Simbu serogroup of the genus Bunyavirus. J Gen Virol 2001, 82(Pt 9):2173-2181.

7. Goller KV, Höper D, Schirrmeier H, Mettenleiter TC, Beer M: Schmallenberg virus as possible ancestor of Shamonda virus. Emerg Infect Dis 2012, 18(10):1644-1646.

8. Kohl A, Bridgen A, Dunn E, Barr JN, Elliott RM: Effects of a point mutation in the $3^{\prime}$ end of the $S$ genome segment of naturally occurring and engineered Bunyamwera viruses. J Gen Virol 2003, 84(Pt 4):789-793.

9. Bilk S, Schulze C, Fischer M, Beer M, Hlinak A, Hoffmann B: Organ distribution of Schmallenberg virus RNA in malformed newborns. Vet Microbiol 2012, 159(1-2):236-238.

10. Elliott RM, Blakqori G: Molecular biology of orthobunyaviruses. In Bunyaviridae. Edited by Plyusnin A, Elliott RM. Norfolk: Caister Academic Press; 2011:1-39.

11. Bowen MD, Jackson AO, Bruns TD, Hacker DL, Hardy JL: Determination and comparative analysis of the small RNA genomic sequences of California encephalitis, Jamestown Canyon, Jerry Slough, Melao, Keystone and Trivittatus viruses (Bunyaviridae, genus Bunyavirus, California serogroup). J Gen Virol 1995, 76(Pt 3):559-572.

12. Vasconcelos HB, Azevedo RS, Casseb SM, Nunes-Neto JP, Chiang JO, Cantuária PC, Segura MN, Martins LC, Monteiro HA, Rodrigues SG, Nunes MR, Vasconcelos PF: Oropouche fever epidemic in Northern Brazil: epidemiology and molecular characterization of isolates. J Clin Virol 2009, 44(2):129-133. 
13. Stram $Y$, Kuznetzova L, Guini M, Rogel A, Meirom R, Chai D, Yadin $H$, Brenner J: Detection and quantitation of akabane and aino viruses by multiplex real-time reverse-transcriptase PCR. J Virol Methods 2004 116(2):147-154.

14. Dunn EF, Pritlove DC, Elliott RM: The S RNA genome segments of Batai, Cache Valley, Guaroa, Kairi, Lumbo, Main Drain and Northway bunyaviruses: sequence determination and analysis. J Gen Virol 1994, 75(Pt 3):597-608.

15. Hall TA: BioEdit: a user-friendly biological sequence alignment editor and analysis program for Windows 95/98/NT. Nucl Acids Symp Ser 1999, 41:95-98.

16. Hoffmann B, Beer M, Schelp C, Schirrmeier H, Depner K: Validation of a real-time RT-PCR assay for sensitive and specific detection of classical swine fever. J Virol Methods 2005, 130(1-2):36-44.

17. Hoffmann B, Depner K, Schirrmeier H, Beer M: A universal heterologous internal control system for duplex real-time RT-PCR assays used in a detection system for pestiviruses. J Virol Methods 2006, 136(1-2):200-209.

18. Toussaint JF, Sailleau C, Breard E, Zientara S, De Clercq K: Bluetongue virus detection by two real-time RT-qPCRs targeting two different genomic segments. J Virol Methods 2007, 140(1-2):115-123.

doi:10.1186/1743-422X-10-327

Cite this article as: Fischer et al:: Development of a pan-Simbu real-time reverse transcriptase PCR for the detection of Simbu serogroup viruses and comparison with SBV diagnostic PCR systems. Virology Journal 2013 10:327.

\section{Submit your next manuscript to BioMed Central and take full advantage of:}

- Convenient online submission

- Thorough peer review

- No space constraints or color figure charges

- Immediate publication on acceptance

- Inclusion in PubMed, CAS, Scopus and Google Scholar

- Research which is freely available for redistribution 